One regrets a certain undervaluing of the contributions of Flohn and Kraus (in these cases perhaps it is lack of thorough acquaintance), also of earlier pioneers like Huntington, Kinzl and Utterström; though C. E. P. Brooks comes in for legitimate criticism (page 213) for "romancing" about the so-called "little ice age" of recent centuries and putting an "interglacial" into it between 1680 and 1740 on littlo evidence-actually the 1690 s aro now known to have been about the coldest decade in Iceland, Norway and Britain, though not in the Alps. Any unfairness has clcarly resulted only from the difficulty of attaining, or expressing, a balanced judgment quickly. Thore is some polemic, probably mainly intended to goad his fellow historians into tackling the subject and producing further critically examined data for scientific analysis. This style of presentation does mean, however', that one has to read a long way before discovering that the author's conclusion (for example, page 31 ) that the climate has been stable during the past two thousand years or more admits of oscillations great enough to allow several hundred years of disastrous advance of the glaciers (Brooks's "little ice age"-a convenient enough lerm) and of the polar sea ice.

Ladurie arrives at sensible estimates for the amplitudes and different period-lengths of the various fluctuations. The great glacier advances roferred to were produced by a variation of average annul mean temperature amounting to only ubout $1^{\circ} \mathrm{C}$. This should be sufficient warning of the precariousness of practical decisions based on an assumed constancy of climate.

The book makes no attempt at meteorological interpretation and contains not a single weather map. The author seems to have much less appreciation of shifts in world procipitation patterns than he has of temperature, though a selection of Fritts ${ }^{5}$ maps of average tree-growth in different decades since 1576 in the western United States are reproduced. Chapters of the book are devoted to: (1) aims of his quest for facts of past climates, (2) the evidence of changes in the forests and vintages, (3) the warming of the climato from 1850 to 1950 , (4) the problems and evidence of the "little ice age" which preceded the recent warming, (5) "working hypotheses" (in reality an assessment of the magnitude and course of the temperature changos which underlay the glacier changes of recent centuries), and (6) the turf moor at Fornau in the Austrian Alps. The last-named brings in a useful survey of the longer span of post-glacial climatic history and much little known detail on the sequence of glacier advances and retreats since $1500 \mathrm{BC}$ in that locality; though it is an extreme course to gencralize the history of Europe's glaciers from the record of a single one as registered in the peat bog near its snout.

I share the author's earnest hope that this book will serve to awaken interest in the elimatic record and encourago many more historians to tako it up. In the long run, the chicf value of the book will, however, be its remarkable documentation, with the quoting or reproduction of many ancient texts and dated maps and pictures, of the glacior advance and retreat in Europe since AD 1200 as well as the tabulated data year by year since AD 1349 of the Hrench vintages and its analysis of how far the vintage variations were controlled by wcathor.

It makes a fuscinating book and one which will be bought for the charm of its remarkable sequonee of pictures of the Rhône glacier and the Chamonix glaciers as well as for reference to the critically examined data it contains.

H. H. ТА $А$ MB

${ }^{1}$ Lamb, H. H., Palaeogeogr., Palaeoclim., Palaeoecol, 1, 13 (Elsevier, Amsterdam, 1965).

2 Titow, J., Econ. Hist. Rev. (1960).

- Proc. Conf, on the Climale of the Eleventh and Sirteenth Centuries-Aspen, Colorado, June 1962, 38 (NCAR, Tech. Note 63-1, Boulder, 1963).

'Buchinsky, I. F., O klimate proslovo Russkoi raminy (The past climate of the Russian plain), Leningrad (Gidrometeoizdat, 1957).

'Fritts, H. C., Monthly Weather Rev., 93. 421 (Tree-Ring Evidence for Climatic Changes in Western North America) (U.S. Dept. of Commerce Weather Burcau, Washington).

\section{LABORATORY PHARMACOLOGY}

Pharmacological Experiments on Isolated Preparations By the staff of the Department of Pharmacology, University of Edinburgh. Pp. 131. (Edinburgh and London: E. and S. Livingstone, Ltd., 1968.) 21 s.

THE publication of this new practical book from Edinburgh will be welcomed by most pharmacologists. Experimental procedures for setting up isolated tissue prepara tions are described in sufficient detail for a novice to attempt these with every expectation of success. The illustrations are simple and helpful.

There is a wealth of information of particular value to those concerned in the preparation of practical classes, notably about concentrations and doses of drugs, most of which are, quite rightly, expressed on a molar basis. The references have been selected for their relevance to practieal details. One appendix tabulates molecular weights and solubilities of drugs. Others deal with the estimation of fiducial limits and the equations of drug-receptor interaction. These are all useful data. An appendix listing the basic apparatus required for the experiments might perhaps be included in a subsequent edition.

The use of capital letters to distinguish pharmacopoeial or approved names from "chemical names when these are simple" is quite unjustified. This convention, not always consistent, coupled with the use of italics for trade names (and for other drugs when these are part of a heading) will confuse rather than help the student.

Tho description of each experiment begins on a new page; the descriptions of the biological preparations themselves, some of which apply to more than one oxporiment, are less easily located-a bolder type rather than italics might be helpful. The table of contents is clearly laid out and obviates the nocessity for an index.

All the experiments described are exclusively on isolated tissues and so can be performed by students without a Home Office licence. It is surprising how much pharmacology can be taught on tissues in vitro. Novertheless, it is essential for pharmacologists to remember that the experiments in this book should form only a part of any practical course in pharmacology. They must be supplemented by demonstrations on anaesthetized animals and if possible by the students experiment. ing on decerebrate, spinal or pithed preparations and on themselves. Perhaps the authors could be persuaded to write a further volume dealing with these aspects of practical pharmacology. It would be as well received as I am confident this one will be. $\quad$ E. W. HorTon

\section{CANCER IN CANADA}

\section{Canadian Cancer Conference}

Vol. 7: Procecdings of the Seventh Canadian Cancer Research Conference, 1966. J. F. Morgan et al. (editors). Pp. 432. (Pergamon Press, 1967.) \$18; £6.

THese volumes serve to bring together the many aspects of cancer research. This latest volume contains twentytwo papers and covers five major areas in the study of cancor. Discussion of cell division and proliferation and of metabolic regulatory systems account for more than half of the contributions. The properties of cell mem. branes, tho offects of radiation on cells, carcinogenesis and cancor cpidomiology take up the remainder of the volume. The papers are all of a reviow nature, but this has not restrained the duthors from presenting their personal views and speculations. Each of the papers is so wide-ranging that it is a pity there is no index to help the reader find particular details quickly. The editors are to be congratulated for achieving a uniformly high standard in the presentation and content of the papers in this uscful volume.
P. W. Banjow 